\title{
Response of Canada thistle (Cirsium arvense) and leafy spurge (Euphorbia esula) clones to chlorsulfuron, clopyralid, and glyphosate ${ }^{1}$
}

\section{J. RAY FRANK and THOMAS J. TWORKOSKI}

Res. Hortic., USDA, ARS, Ft. Detrick, Frederick, MD 21702, and Plant Physiol., USDA, ARS, Keameysville, WV 25430 .

\begin{abstract}
:
Response of clones of Canada thistle from North America and leafy spurge from North America and Eurasia to treatment with chlorsulfuron, clopyralid, and glyphosate was determined. Roots of Canada thistle plants from different locations responded differentially to injury from chlorsulfuron and clopyralid but not to glyphosate. Clones of Canada thistle varied significantly in response to all herbicide treatments. Roots of leafy spurge plants from different locations were differentially susceptible to injury from glyphosate. Clones of leafy spurge varied significantly for all responses to each herbicide. The differential effects of chlorsulfuron, glyphosate, and clopyralid on clones of Canada thistle and leafy spurge suggest that genetically-based differences may account for the failure of the herbicides to kill all plants within collection locations or between collection locations. Cross tolerance to the herbicides was not found in leafy spurge or Canada thistle.
\end{abstract}

\section{Nomenclature:}

Chlorsulfuron, 2-chloro- $N$-[[(4-methoxy-6-methyl-1,3,5-triazin-2-yl) amino]carbonyl]benzenesulfonamide; clopyralid,3,6-dichloro-2-pyridinecarboxylic acid; glyphosate, $N$-(phosphonomethyl)glycine; Canada thistle,

\footnotetext{
${ }^{1}$ Received for publication Sept. 7, 1993 and in revised form May 4, 1994. Names are necessary to report factually on available data; however, the USDA neither guarantees nor warrants the standard of the product, and the use of the name by USDA implies no approval of the product to the exclusion of others that may also be suitable.
} 
Cirsium arvense (L.) Scop. \# CIRAR; leafy spurge, Euphorbia esula L. \# EPHES.

\section{Additional index words:}

Clones, CIRAR, EPHES.

\section{Introduction}

Canada thistle and leafy spurge are perennial weeds of major importance in pastures and non-crop areas of North America $(1,9,15)$. Canada thistle was introduced from Europe (13) and leafy spurge from Asia $(7,15)$. Control is difficult because of their large root systems that propagate vegetatively $(11,21,23)$. Within each species, descendants produced vegetatively from a single original seedling (clones), have been distinguished based on characteristics such as leaf and flower morphology $(8,14,16,22,24)$, and herbicide resistance $(3,5,11,15,29)$.

Ecotypes, i.e., genetic variants of a species adapted to a particular environment that remain interfertile with other members of the species (30), have been distinguished based on morphology (15), phenology (17), and herbicide susceptibility $(18,26,31)$. Ecotypes of Canada thistle were differentially susceptible to 2,4-D [(2,4-dichlorophenoxy)acetic acid] $(18,20)$, dicamba (3,6-dichloro-2-methoxybenzoic acid), and amitrole (1 $H$-1,2,4tria- zol-3-amine) $(17,26)$.

Populations of several annual species of weeds have developed tolerance to herbicide in response to continued use of a single chemical (19). In some deep rooted perennials, herbicide tolerance could involve growth of meristems that avoided exposure to the herbicide. For example, adventitious shoots commonly develop from roots of Canada thistle whose shoots were treated with certain herbicides (28). Although herbicide-resistant weeds are probably present in most weed populations (27), the frequency of resistant individuals and the degree of resistance among individual clones is not known.

Work has been done to identify environmental conditions and stages of development at which Canada thistle is susceptible to herbicides $(4,10)$. Some experiments have focused on one or few clones of Canada thistle $(20,26)$. Little work has been done to characterize responses of Canada thistle to herbicides based on intra- and inter-location genetic differences. Chlorsulfuron, clopyralid, and glyphosate are effective herbicides for control of Canada thistle $(12,25,28,32)$. Potential for resistance to these herbicides could affect weed control strategies.

Research was conducted to determine whether herbicide-tolerant clones of Canada thistle and leafy spurge, collected from widely separated locations, could be identified.

\footnotetext{
${ }^{2}$ Letters following this symbol are a WSSA-approved computer code from a composite List of Weeds, Revised, 1989. Available from WSSA, 1508 West University Ave., Champaign, IL 61821-3133.
} 
Knowledge of clonal variation is significant to future research in which low herbicide rates may be incorporated with plant pathogens for integrated weed management. The objective was to determine differences in tolerance of Canada thistle and leafy spurge to three translocated herbicides with different modes of action for plants collected from different locations and sites within a location.

\section{Materials and methods}

\section{Canada thistle}

Plants were propagated from roots collected at locations in the U.S. and Canada (Table 1). Clones were defined as plants propagated from roots collected from a single plant at each location. Three clones were collected at each location. Individual clones were subcultured several times to maintain plant vigor. Experimental plants were at least four vegetative generations from the original collection to reduce environmental effects of the collection location on clone morphology and physiology.

\section{Table 1. Clones of Canada thistle and leafy spurge.}

\begin{tabular}{|c|c|c|}
\hline $\mathrm{FD} \#^{\mathrm{a}}$ & Clone no. $^{\mathrm{b}}$ & Source and location \\
\hline \multicolumn{3}{|l|}{ Canada thistle } \\
\hline CAN $1,2,3$ & & K. Neil Harker, Lacombe, Alberta, Canada \\
\hline CT1 2,3 & & Kogue Nursery, Hartford Co., Connecticut \\
\hline IL1, 2, 3 & & Dan Madix and Loyd Wax, Champaign Co., Illinois \\
\hline $\operatorname{MD} 4,5,6$ & & Peter Kujawski, Frederick Co., Maryland \\
\hline $\mathrm{NE} 1,2,3$ & & Robert Wilson, Scotts Bluff Co., Nebraska \\
\hline Leafy spurge & & Balkans \\
\hline BK44 & 1982 Н 002 & Sherry Turner, Mazaszaszar, Hungary \\
\hline BK48 & 1980 YU 001 & $\begin{array}{l}\text { Gaitano Campobasso and Pasquale Pecora, Loznica, } \\
\text { Yugoslavia }\end{array}$ \\
\hline BK54 & 1982 I 001 & $\begin{array}{l}\text { R. Vonmoos, Abeton, Italy } \\
\text { Eurasia }\end{array}$ \\
\hline EU53 & 1979 TU 001 & Paul Dunn, Erzurum, Turkey \\
\hline EU86 & 1991 RU 002 & Rick Bennett, Mahuchkala Dagestan, USSR \\
\hline EU88 & 1991 R 001 & $\begin{array}{l}\text { Rick Bennett and Massimo Cristofaro, Galati, Romania } \\
\text { Montana }\end{array}$ \\
\hline MT79 & 1991 МТ 001 & Virgil Dupuis, Polson \\
\hline MT7 & 1989 МТ 001 & Peter Fay and Brad Muller, Bozeman \\
\hline MT83 & 1991 МТ 002 & $\begin{array}{l}\text { Sandy Saufferer, Big Timber } \\
\text { Nebraska }\end{array}$ \\
\hline NE3 & 1989 NE 003 & Gene Lehnert, Ainsworth \\
\hline NE5 & 1989 NE 004 & Robert Sprentall and Floyd Reed, Chadron \\
\hline NE6 & 1989 NE 005 & $\begin{array}{l}\text { Bob Masters, Lincoln } \\
\text { North Dakota }\end{array}$ \\
\hline ND9 & 1978 ND 001 & Rod Lym and Cal Messersmith, Sheldon \\
\hline ND11 & 1984 ND 001 & Rod Lym, Fargo \\
\hline ND72 & 1990 ND 001 & Sandy Saufferer, Mandan \\
\hline
\end{tabular}

${ }^{\mathrm{a}}$ Fort Detrick accession number. Each number represents an individual clone. Three clones were collected from each of the Canada thistle locations. For example, CAN 1, CAN2, and CAN3 were collected from Lacombe, Alberta, Canada. ${ }^{\mathrm{b}}$ Clone number assigned to leafy spurge follows Great Plains Council 14 Committee (6). The first number represents year collected. 
Plants (225 per clone) were propagated from single 5-cm root cuttings and grown in the greenhouse for 8 weeks in 1-L pots filled with loam, sand, and peat moss (1:1:1 ratio by volume). Plants were watered as needed, generally $40 \mathrm{ml} / \mathrm{pot} /$ day. Plants were grouped by size before treatment for a randomized complete block design. The average stem length for all clones ranged from 4 to $19 \mathrm{~cm}$ representing plants in the early bolt phase of growth. One of three herbicides was then applied to plant foliage in a moving nozzle sprayer chamber ${ }^{3}$. All spray treatments were applied in $350 \mathrm{~L} /$ ha carrier at 140 $\mathrm{kPa}(8002 \text { Tee Jet flat fan nozzle })^{4}$.

Chlorsulfuron was applied at 0.2 and $0.4 \mathrm{~kg} / \mathrm{ha}$, clopyralid at 25 and $50 \mathrm{~g} / \mathrm{ha}$, and glyphosate at 0.5 and $1.0 \mathrm{~kg} / \mathrm{ha}$. Untreated plants were included as controls. Herbicide rates were based on preliminary experiments. Data from these experiments suggested that both treatment rates would be injurious and provide differential responses among clones. Canada thistle treated with chlorsulfuron at $0.2 \mathrm{~kg} / \mathrm{ha}$ was at the lowest recommended rate, and $0.4 \mathrm{~kg} / \mathrm{ha}$ was more than the highest recommended rate (2). Clopyralid and glyphosate treatments were both lower than recommended control rates.

\section{Leafy spurge}

Single plants were obtained from cooperators located in North America and Eurasia and assigned an accession number and a clone number using the numbering system established by Davis (6) (Table 1). As with Canada thistle, individual plants were collected to reasonably ensure that different genotypes were obtained. Experimental plants were propagated from root cuttings of plants that were at least the third vegetative generation in the greenhouse.

Plants were propagated from 4- to 8-cm root cuttings and grown under the same conditions as described for Canada thistle. Plants were treated when they were 8 weeks old and were grouped by size in a randomized complete block design. Average stem length for clones ranged from 5 to $19 \mathrm{~cm}$. Herbicides were applied as with Canada thistle. Chlorsulfuron was applied at 0.04 and $0.4 \mathrm{~kg} / \mathrm{ha}$, clopyralid 0.8 and $1.6 \mathrm{~kg} / \mathrm{ha}$, and glyphosate at 1.0 and $2.0 \mathrm{~kg} / \mathrm{ha}$. Untreated plants were included as controls. Again, herbicide rates were based on preliminary experiments which suggested that differential responses among clones could be detected. Leafy spurge was treated with chlorsulfuron at higher than the recommended rates of 0.009 to $0.026 \mathrm{~kg} / \mathrm{ha}$. Clopyralid treatments were also at rates higher than recommendations $(0.28$ to $0.56 \mathrm{~kg} / \mathrm{ha})$. Glyphosate treatments were within the recommended rates of 1.1 to $4.5 \mathrm{~kg} / \mathrm{ha} \mathrm{(2).}$

Canada thistle and leafy spurge were maintained in a greenhouse at $26 \pm 5^{\circ} \mathrm{C}$, a 14 hour photoperiod, and $570 \mu \mathrm{E} / \mathrm{m}^{2} / \mathrm{s}$ photosynthetically active radiation measured at noon. Day length after treatment ranged from 12 to 16 hours. Natural sunlight was supplemented on cloudy days with 12 hours of light from full spectrum metal halide lamps (280 $\mu \mathrm{E} / \mathrm{m}^{2} / \mathrm{s}$ photosynthetic photoflux density at canopy height, complete cloud cover).

\footnotetext{
${ }^{3}$ Richard Scientific, Inc., 250 Bel Marin Keys Bldg., Suite D3, Navajo, CA 94949.

${ }^{4}$ Spraying Systems Co., North Ave., Wheaton, IL 60188.
} 
Shoot injury and height were measured 2 weeks after treatment and then all shoots were cut at soil level. Regrowth height of adventitious shoots was measured every 2 weeks for 12 weeks and then injury ratings and dry weights of root and shoot were measured. Injury ratings were based on a 0 to 10 scale where $0=$ no injury and $10=$ dead plant, visually estimated by three people and then averaged.

Each herbicide-species experiment was performed once with a factorial design, and the effects of herbicide rate, collection location, and clone were tested. Each clone was replicated at least five times (i.e., five cuttings of each clone) and at least three clones were used from each collection location. Overall effects of herbicide rate, collection location, and clone are presented as analysis of variance and individual location and clone means were compared using Fisher's protected LSD.

Summaries of statistical significance are presented to provide an overview of treatment effects on the variety of relevant response variables. Root dry weights are presented for individual location-by-rate and clone-by-rate effects because root dry weights reflect long-term herbicide injury.

\section{Results and discussion}

\section{Canada thistle}

The treatment rate of each herbicide affected all variables measured (data not shown). Collection location, affected Canada thistle shoot regrowth and final shoot injury in plants treated with glyphosate but not with chlorsulfuron and clopyralid (Table 2). A significant location-by-rate interaction also occurred for regrowth height in Canada thistle treated with glyphosate (Table 2). Regrowth height of Canada thistle from Illinois and Connecticut was greater than that of collections from Nebraska, Canada, and Maryland 12 weeks after treatment with glyphosate at $0.5 \mathrm{~kg} / \mathrm{ha}$ (data not shown). Clones from Illinoi and Connecticut receiving no glyphosate had lower root dry weight than clones from other locations (Table 3). The vigorous regrowth from roots with less biomass suggests that root-stored reserves were not limiting. Plants of Canada thistle from one location varied in their susceptibility to chlorsulfuron, glyphosate, and clopyralid. No single herbicide was most effective on plants from each location.

Root injury to clones of Canada thistle by chlorsulfuron and clopyralid varied among collection locations (Table 2). The greatest root injury following treatment with chlorsulfuron occurred in Canada thistle collected from Illinois (data not shown). There was a significant location-by-rate interaction for root dry weight when clopyralid was applied (Table 2). This interaction may be associated with the response to clopyralid at $25 \mathrm{~g} / \mathrm{ha}$ where Canada thistle from Illinois, Maryland, and Connecticut had lower root dry weights than Canada thistle from Canada and Nebraska (Table 3). It is possible that Canada thistle from Canada and Nebraska were more tolerant of low rates of clopyralid but the physiological cause of such tolerance is unknown. At high clopyralid rates, there was little difference in root dry weights among locations (Table 3).

Page 5 of 13 
The effect of clone was significant on nearly all response variables for the three herbicides (Table 2). Root dry weights of clones NE1 and IL2 treated with high rates of chlorsulfuron were inhibited more than $95 \%$ (Table 3 ).

Table 2. Statistical summary of the effects of collection location, clone, and herbicide rate on herbicide efficacy in Canada thistle at 2 and 12 weeks after treatment.

\begin{tabular}{|c|c|c|c|c|c|c|c|}
\hline \multirow{3}{*}{$\begin{array}{l}\text { Source of } \\
\text { variation }\end{array}$} & \multicolumn{3}{|c|}{$2 \mathrm{wk}$} & \multicolumn{4}{|c|}{$12 \mathrm{wk}$} \\
\hline & \multirow[b]{2}{*}{ Height } & \multirow[b]{2}{*}{ Shoot injury } & \multirow[b]{2}{*}{ Regrowth height } & \multirow[b]{2}{*}{ Shoot injury } & \multirow[b]{2}{*}{ Root injury } & \multicolumn{2}{|c|}{ Dry Weight } \\
\hline & & & & & & Shoot & Root \\
\hline & & & & $\mathrm{P}>\mathrm{F}^{\mathrm{a}}$ & & & \\
\hline \multicolumn{8}{|l|}{ Chlorsulfuron } \\
\hline $\begin{array}{l}\text { Collection } \\
\text { location (L) }\end{array}$ & 0.036 & 0.365 & 0.812 & 0.136 & 0.011 & 0.808 & 0.044 \\
\hline Clone (C) & 0.001 & 0.001 & 0.001 & 0.001 & 0.001 & 0.001 & 0.001 \\
\hline L x Rate (R) & 0.001 & 0.636 & 0.430 & 0.137 & 0.008 & 0.983 & 0.657 \\
\hline $\mathrm{CxR}$ & 0.001 & 0.001 & 0.001 & 0.002 & 0.001 & 0.001 & 0.001 \\
\hline CxRxL & 0.021 & 0.001 & 0.001 & 0.030 & 0.001 & 0.001 & 0.001 \\
\hline \multicolumn{8}{|l|}{ Clopyralid } \\
\hline $\begin{array}{l}\text { Collection } \\
\text { location (L) }\end{array}$ & 0.137 & 0.801 & 0.561 & 0.313 & 0.019 & 0.045 & 0.024 \\
\hline Clone $(\mathrm{C})$ & 0.001 & 0.001 & 0.006 & 0.009 & 0.001 & 0.093 & 0.001 \\
\hline L x Rate (R) & 0.861 & 0.699 & 0.204 & 0.372 & 0.025 & 0.007 & 0.002 \\
\hline $\mathrm{CxR}$ & 0.701 & 0.001 & 0.001 & 0.120 & 0.001 & 0.068 & 0.001 \\
\hline CxRxL & 0.478 & 0.001 & 0.001 & 0.183 & 0.080 & 0.693 & 0.052 \\
\hline \multicolumn{8}{|l|}{ Glyphosate } \\
\hline $\begin{array}{l}\text { Collection } \\
\text { location (L) }\end{array}$ & 0.001 & 0.735 & 0.001 & 0.002 & 0.667 & 0.001 & 0.071 \\
\hline Clone (C) & 0.001 & 0.041 & 0.001 & 0.001 & 0.001 & 0.001 & 0.001 \\
\hline L x Rate (R) & 0.001 & 0.023 & 0.033 & 0.089 & 0.077 & 0.399 & 0.103 \\
\hline $\mathrm{CxR}$ & 0.774 & 0.016 & 0.015 & 0.002 & 0.001 & 0.005 & 0.001 \\
\hline CxRxL & 0.999 & 0.337 & 0.304 & 0.050 & 0.002 & 0.015 & 0.001 \\
\hline
\end{tabular}

Clones CAN1, CT1, and CT3 were less affected by high rates of chlorsulfuron, being inhibited approximately $75 \%$. Clones from Canada, Nebraska, and Illinois, treated with glyphosate, had lower shoot (data not shown) and root dry weight (Table 3) than those from Maryland and Connecticut. After clopyralid treatment at the high rate, clone IL3 regrew and root dry weight was greater than that of other clones (Table 3 ).

Individual Canada thistle within a population can vary considerably in appearance and growth characteristics (14). Based on results from this study, populations vary considerably in response to herbicides. Our results agree with the effect of atrazine (6-chloro- 
$N$-ethyl- $N^{\prime}$-(1-methylethyl)-1,3,5-triazine-2,4-diamine) on selected Canada thistle genotypes (4). These data demonstrate that clones of Canada thistle reacted differently to each herbicide. Such results might be expected since the herbicides used in this experiment have different modes of action: glyphosate inhibits the biosynthesis of aromatic amino acids (11), chlorsulfuron inhibits production of the amino acids valine and isoleucine (25), and clopyralid stimulates cell growth. We found no evidence of cross-tolerance to these herbicides within clones of Canada thistle.

Table 3. Dry weights of Canada thistle roots from clones collected at five locations in North America 12 weeks after treatment with three translocated herbicides.

\begin{tabular}{|c|c|c|c|c|c|}
\hline \multirow[b]{2}{*}{ Collection location } & \multirow[b]{2}{*}{ FD \# } & \multicolumn{4}{|c|}{ Herbicide rate $^{\mathrm{a}}$} \\
\hline & & 0 & $1 \mathrm{x}$ & $2 \mathrm{x}$ & LSD $0.05^{b}$ \\
\hline & & & - g & 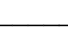 & 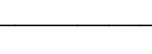 \\
\hline \multicolumn{6}{|l|}{ Chlorsulfuron } \\
\hline \multirow[t]{4}{*}{ Canada } & CAN1 & 4.5 & 1.2 & 1.1 & 2.0 \\
\hline & CAN2 & 6.3 & 0.5 & 0.5 & 1.7 \\
\hline & CAN3 & 4.3 & 0.8 & 0.6 & 0.8 \\
\hline & Mean $^{\mathrm{e}}$ & 5.0 & 0.8 & 0.7 & 0.9 \\
\hline \multirow[t]{4}{*}{ Connecticut } & CT1 & 5.0 & 1.5 & 1.4 & 1.2 \\
\hline & CT2 & 7.0 & 1.6 & 1.1 & 1.5 \\
\hline & CT3 & 3.8 & 1.4 & 1.2 & 1.3 \\
\hline & Mean & 5.3 & 1.5 & 1.2 & 0.9 \\
\hline \multirow[t]{4}{*}{ Illinois } & IL1 & 3.3 & 0.1 & 0.1 & 1.3 \\
\hline & IL2 & 2.0 & 0.9 & 0 & 1.7 \\
\hline & IL3 & 2.7 & 0.5 & 0.3 & 1.4 \\
\hline & Mean & 2.7 & 0.5 & 0.1 & 0.8 \\
\hline \multirow[t]{4}{*}{ Maryland } & MD4 & 2.1 & 0.7 & 0.7 & 0.7 \\
\hline & MD5 & 6.7 & 1.2 & 0.8 & 1.3 \\
\hline & MD6 & 2.0 & 0.8 & 0.6 & 0.6 \\
\hline & Mean & 3.6 & 0.9 & 0.7 & 1.1 \\
\hline \multirow[t]{4}{*}{ Nebraska } & NE1 & 4.4 & 0.5 & 0.1 & 0.6 \\
\hline & NE2 & 3.6 & 1.2 & 0.8 & 1.1 \\
\hline & NE3 & 3.9 & 0.7 & 0.2 & 1.5 \\
\hline & Mean & 4.0 & 0.8 & 0.4 & 0.6 \\
\hline \multicolumn{6}{|l|}{ Clopyralid } \\
\hline \multirow[t]{4}{*}{ Canada } & CAN1 & 3.0 & 0.3 & 0.2 & 1.1 \\
\hline & CAN2 & 3.2 & 0.2 & 0.1 & 0.6 \\
\hline & CAN3 & 3.5 & 1.2 & 0 & 1.3 \\
\hline & Mean & 3.2 & 0.5 & 0.1 & 0.6 \\
\hline \multirow[t]{4}{*}{ Connecticut } & CT1 & 4.2 & 0.1 & 0.1 & 0.3 \\
\hline & $\mathrm{CT} 2$ & 4.3 & 0.1 & 0 & 0.7 \\
\hline & CT3 & 4.1 & 0.2 & 0 & 1.2 \\
\hline & Mean & 4.2 & 0.1 & 0.1 & 0.4 \\
\hline
\end{tabular}




\begin{tabular}{|c|c|c|c|c|c|}
\hline \multirow[b]{2}{*}{ Collection location } & \multirow[b]{2}{*}{ FD \# } & \multicolumn{4}{|c|}{ Herbicide rate $^{\mathrm{a}}$} \\
\hline & & 0 & $1 \mathrm{x}$ & $2 \mathrm{x}$ & LSD $0.05^{\mathrm{b}}$ \\
\hline & & & $-\mathrm{g}$ & & \\
\hline \multirow{4}{*}{ Illinois } & IL1 & 2.4 & 0.2 & 0 & 0.9 \\
\hline & IL2 & 0.9 & 0.1 & 0 & 0.6 \\
\hline & IL3 & 1.2 & 0.6 & 0.6 & 0.4 \\
\hline & Mean & 1.5 & 0.3 & 0.2 & 0.4 \\
\hline \multirow[t]{4}{*}{ Maryland } & MD4 & 3.6 & 0.1 & 0 & 1.5 \\
\hline & MD5 & 4.3 & 0.1 & 0.1 & 1.0 \\
\hline & MD6 & 2.6 & 0.6 & 0.1 & 0.5 \\
\hline & Mean & 3.5 & 0.3 & 0.1 & 0.7 \\
\hline \multirow[t]{4}{*}{ Nebraska } & NE1 & 4.8 & 0.8 & 0 & 1.8 \\
\hline & NE2 & 2.7 & 0 & 0 & 1.3 \\
\hline & NE3 & 3.0 & 0.3 & 0 & 1.3 \\
\hline & Mean & 3.5 & 0.4 & 0 & 0.8 \\
\hline \multicolumn{6}{|l|}{ Glyphosate } \\
\hline \multirow[t]{4}{*}{ Canada } & CAN1 & 3.8 & 0.5 & 0.2 & 1.3 \\
\hline & CAN2 & 2.3 & 0.7 & 0.1 & 1.0 \\
\hline & CAN3 & 2.6 & 0.4 & 0 & 1.0 \\
\hline & Mean & 2.9 & 0.5 & 0.1 & 0.6 \\
\hline \multirow[t]{4}{*}{ Connecticut } & CT1 & 3.4 & 1.2 & 0.8 & 1.2 \\
\hline & CT2 & 2.7 & 1.8 & 0.2 & 1.4 \\
\hline & CT3 & 1.2 & 1.7 & 0.9 & N S \\
\hline & Mean & 2.4 & 1.6 & 0.6 & 0.8 \\
\hline \multirow[t]{4}{*}{ Illinois } & IL1 & 1.4 & 0.4 & 0 & 0.9 \\
\hline & IL2 & 1.3 & 0.1 & 0 & 0.5 \\
\hline & IL3 & 3.0 & 1.1 & 0 & 1.8 \\
\hline & Mean & 1.9 & 0.5 & 0 & 0.6 \\
\hline \multirow[t]{4}{*}{ Maryland } & MD4 & 1.7 & 1.2 & 0.8 & NS \\
\hline & MD5 & 4.0 & 2.0 & 0.6 & 1.7 \\
\hline & MD6 & 2.4 & 2.1 & 1.3 & NS \\
\hline & Mean & 2.7 & 1.8 & 0.9 & 0.8 \\
\hline \multirow[t]{4}{*}{ Nebraska } & NE1 & 3.9 & 0.7 & 0.1 & 1.0 \\
\hline & NE2 & 4.0 & 0.7 & 0.1 & 0.5 \\
\hline & NE3 & 2.6 & 0.8 & 0 & 0.8 \\
\hline & Mean & 3.5 & 0.7 & 0.1 & 0.5 \\
\hline
\end{tabular}

${ }^{\mathrm{a}}$ The $1 \mathrm{x}$ and $2 \mathrm{x}$ rates were chlorsulfuron at 0.2 and $0.4 \mathrm{~kg} / \mathrm{ha}$, glyphosate at 0.5 and $1.0 \mathrm{~kg} / \mathrm{ha}$, and clopyralid at 25 and $50 \mathrm{~g} / \mathrm{ha}$.

${ }^{b}$ Fisher's Protected LSD for one effect of rate (row) of each herbicide within each location.

${ }^{\mathrm{c}}$ Mean represents the average response for three clones from a collection location.

${ }^{\mathrm{d}} \mathrm{NS}=$ non-significant at 0.05 or less. 
Saidak and Marriage (26) demonstrated variability in Canada thistle ecotype response to glyphosate in the field. Short-term injury variability was evident but season-long control of regrowth did not differ among ecotypes. We found regrowth and root injury to vary among clones 12 weeks after application of glyphosate, clopyralid, or chlorsulfuron in the greenhouse. It is likely that Canada thistle response to herbicides in the field will be a function of environment and growth stage as well as genotype.

\section{Leafy spurge}

Chlorsulfuron and glyphosate were highly effective on leafy spurge (Table 4), but clopyralid was ineffective (data not shown).

Leafy spurge plants collected from different locations and treated with glyphosate had the same shoot injury 2 weeks after treatment and shoot regrowth after 12 weeks (Table 4), Root injury and dry weight were different among location following glyphosate treatment (Table 4). The differential injury response may reflect different absorption or translocation of glyphosate among leafy spurge clones. No significant effects related to location were observed with chlorsulfuron or clopyralid and no location-by-rate interaction occurred with any herbicide 12 weeks after treatment (Table 4).

Clonal variation was significant for all response variables with all three herbicides (Table 4). Plants from Eurasia, Montana, and North Dakota, when treated with glyphosate, had lower root dry weights than those from other locations (Table 5). Root dry weights of clones MT7, ND9, and ND72 were strongly reduced by chlorsulfuron at 0.4 $\mathrm{kg} / \mathrm{ha}$ (Table 5).

Leafy spurge plants from different collection locations and clones within the same location responded differentially to glyphosate (Table 4). Collection location had no significant effect in response to chlorsulfuron and clopyralid. In contrast, Barreto et al. (3) found that clones from 12 locations in the United States were differentially susceptible to 2,4-D, picloram (4-amino-3,5,6-trichloro-2pyridinecarboxylic acid), and amitrole.

Gottrup et al. (11) tried to determine the basis for differential sensitivity to glyphosate in Canada thistle and leafy spurge. They found that the herbicide uptake and translocation was similar for both species and also that more glyphosate was retained on Canada thistle due to its leaf size and orientation than on leafy spurge. The differential sensitivity between the two species seemed to indicate that under field conditions, Canada thistle intercepted and retained more spray than leafy spurge as a result of differences in leaf number, size, shape, arrangement, and potential for wettability. Morphological variations among clones may have some impact on the differential rate responses we observed.

Differential herbicide susceptibility in Canada thistle and leafy spurge was evident in these greenhouse experiments. By growing the plants in a common environment, the influence of clone and collection location (and, therefore, possibly biotype) were determined. The results indicate considerable difference in clone-to-clone response within collection location and less difference in location-to-location response. Such clonal differences within a population underscore the importance of avoiding repeated applications of one herbicide. Tolerant clones could become the dominant weed genotype with continuous use of one herbicide or other herbicides with the same mode of function. Fortu-

Page 9 of 13 
nately, clones of Canada thistle and leafy spurge that were tolerant to one of the herbicides were susceptible to at least one herbicide representing another mode of action.

Table 4. Statistical summary of the effects of collection location, clone, and herbicide rate on herbicide efficacy in leafy spurge at 2 and 12 weeks after treatment.

\begin{tabular}{|c|c|c|c|c|c|c|c|}
\hline \multirow{3}{*}{$\begin{array}{l}\text { Source of } \\
\text { variation }\end{array}$} & \multicolumn{3}{|c|}{$2 \mathrm{wk}$} & \multicolumn{4}{|c|}{$12 \mathrm{wk}$} \\
\hline & \multirow[b]{2}{*}{ Height } & \multirow{2}{*}{$\begin{array}{l}\text { Shoot } \\
\text { injury }\end{array}$} & \multirow{2}{*}{$\begin{array}{l}\text { Regrowth } \\
\text { height }\end{array}$} & \multirow{2}{*}{$\begin{array}{l}\text { Shoot } \\
\text { injury }\end{array}$} & \multirow{2}{*}{$\begin{array}{l}\text { Root } \\
\text { injury }\end{array}$} & \multicolumn{2}{|c|}{ Dry weight } \\
\hline & & & & & & Shoot & Root \\
\hline & & & & $\mathrm{P}>\mathrm{Fa}$ & & & 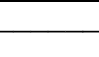 \\
\hline \multicolumn{8}{|l|}{ Chlorsulfuron } \\
\hline $\begin{array}{l}\text { Collection } \\
\text { location (L) }\end{array}$ & 0.195 & 0.515 & 0.226 & 0.314 & 0.131 & 0.845 & 0.242 \\
\hline Clone (C) & 0.001 & 0.001 & 0.001 & 0.001 & 0.001 & 0.001 & 0.001 \\
\hline Rate (R) & 0.001 & 0.031 & 0.001 & 0.001 & 0.001 & 0.001 & 0.001 \\
\hline $\mathrm{L} \times \mathrm{R}$ & 0.499 & 0.524 & 0.762 & 0.672 & 0.488 & 0.593 & 0.241 \\
\hline $\mathrm{C} \times \mathrm{R}$ & 0.345 & 0.484 & 0,003 & 0.005 & 0.001 & 0.001 & 0.002 \\
\hline $\mathrm{C} \times \mathrm{R} \times \mathrm{L}$ & 0.338 & 0.427 & 0.002 & 0.006 & 0.000 & 0.001 & 0.031 \\
\hline \multicolumn{8}{|l|}{ Copyralid } \\
\hline $\begin{array}{l}\text { Collection } \\
\quad \text { location (L) }\end{array}$ & 0.594 & 0.080 & 0.924 & 0.313 & 0.885 & 0.746 & 0.552 \\
\hline Clone (C) & 0.001 & 0.001 & 0.001 & 0.009 & 0.001 & 0.001 & 0.001 \\
\hline Rate (R) & 0.013 & 0.001 & 0.142 & 0.001 & 0.410 & 0.220 & 0.084 \\
\hline $\mathrm{L} \times \mathrm{R}$ & 0.660 & 0.065 & 0.517 & 0.372 & 0.688 & 0.394 & 0.514 \\
\hline $\mathrm{C} \times \mathrm{R}$ & 0.991 & 0.376 & 0.613 & 0.120 & 0.771 & 0.887 & 0.992 \\
\hline $\mathrm{C} \times \mathrm{R} \times \mathrm{L}$ & 0.949 & 0.768 & 0.566 & 0.755 & 0.611 & 0.858 & 0.969 \\
\hline \multicolumn{8}{|l|}{ Glyphosate } \\
\hline $\begin{array}{l}\text { Collection } \\
\quad \text { location (L) }\end{array}$ & 0.001 & 0.189 & 0.078 & 0.002 & 0.033 & 0.030 & 0.017 \\
\hline Clone (C) & 0.001 & 0.001 & 0.001 & 0.001 & 0.001 & 0.001 & 0.001 \\
\hline Rate (R) & 0.001 & 0.001 & 0.001 & 0.001 & 0.001 & 0.001 & 0.001 \\
\hline $\mathrm{L} \times \mathrm{R}$ & 0.359 & 0.007 & 0.624 & 0.089 & 0.282 & 0.157 & 0.220 \\
\hline $\mathrm{C} \times \mathrm{R}$ & 0.843 & 0.001 & 0.001 & 0.002 & 0.001 & 0.001 & 0.001 \\
\hline $\mathrm{C} \times \mathrm{R} \times \mathrm{L}$ & 0.782 & 0.001 & 0.001 & 0.002 & 0.001 & 0.001 & 0.001 \\
\hline
\end{tabular}

a $\mathrm{P}>\mathrm{F}$ of 0.05 or less was designated as significant in this experiment [based on ANOVA]. 
Table 5. Dry weights of leafy spurge roots from clones collected at locations in Europe, Asia, and North America 12 weeks after treatment with two translocated herbicides.

\begin{tabular}{|c|c|c|c|c|c|}
\hline \multirow[b]{2}{*}{ Collection location } & \multirow[b]{2}{*}{ FD \# } & \multicolumn{4}{|c|}{ Herbicide rate $^{\mathrm{a}}$} \\
\hline & & 0 & $1 \mathrm{x}$ & $2 x$ & LSD $0.05^{\mathrm{b}}$ \\
\hline & & & 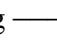 & & 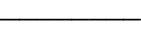 \\
\hline \multicolumn{6}{|l|}{ Chlorsulfuron } \\
\hline \multirow[t]{4}{*}{ Balkans } & BK44 & 0.8 & 0.8 & 0 & $\mathrm{NS}^{\mathrm{c}}$ \\
\hline & BK54 & I d & - & - & - \\
\hline & BK48 & 2.2 & 2.9 & 2.5 & NS \\
\hline & Mean $^{\mathrm{e}}$ & 1.5 & 1.9 & 1.3 & NS \\
\hline \multirow[t]{4}{*}{ Eurasia } & EU53 & 0 & 0 & 0 & NS \\
\hline & EU86 & 2.4 & 1.3 & 0.8 & 1.0 \\
\hline & EU88 & 0 & 0 & 0 & NS \\
\hline & Mean & 0.9 & 0.5 & 0.3 & NS \\
\hline \multirow[t]{4}{*}{ Montana } & MT7 & 1.8 & 0.6 & 0 & 1.1 \\
\hline & MT79 & - & - & - & \\
\hline & MT83 & - & - & - & \\
\hline & Mean & & & & \\
\hline \multirow[t]{4}{*}{ Nebraska } & NE3 & 3.1 & 0.9 & 0.6 & 0.5 \\
\hline & NE6 & 2.6 & 2.8 & 0.5 & 1.5 \\
\hline & NE5 & 3.3 & 2.0 & 0.6 & 1.3 \\
\hline & Mean & 3.0 & 1.9 & 0.6 & 0.7 \\
\hline \multirow[t]{4}{*}{ North Dakota } & ND9 & 1.3 & 1.5 & 0 & 1.2 \\
\hline & ND11 & 0.2 & 0 & 0 & NS \\
\hline & ND72 & 2.0 & 0.1 & 0 & 1.0 \\
\hline & Mean & 1.2 & 0.5 & 0 & 0.6 \\
\hline \multicolumn{6}{|l|}{ Glyphosate } \\
\hline \multirow[t]{4}{*}{ Balkans } & BK44 & 4.4 & 0.1 & 0.1 & 0.5 \\
\hline & BK54 & 2.7 & 0.1 & 0.1 & 1.5 \\
\hline & BK48 & 5.8 & 2.7 & 0.1 & 2.3 \\
\hline & Mean & 4.3 & 1.0 & 0.1 & 1.1 \\
\hline \multirow[t]{4}{*}{ Eurasia } & EU53 & 2.0 & 0.1 & 0.1 & NS \\
\hline & EU86 & 3.3 & 0.1 & 0.1 & 0.5 \\
\hline & EU88 & 2.2 & 0.2 & 0.1 & 1.2 \\
\hline & Mean & 1.9 & 0.1 & 0.1 & 0 \\
\hline \multirow[t]{4}{*}{ Montana } & MT7 & 2.6 & 0.1 & 0.1 & 2.2 \\
\hline & MT79 & 2.0 & 0.1 & 0.1 & 1.4 \\
\hline & MT83 & 2.1 & 0.1 & 0.1 & 1.5 \\
\hline & Mean & 2.2 & 0.1 & 0.1 & 0.9 \\
\hline \multirow[t]{4}{*}{ Nebraska } & NE3 & 3.1 & 0.1 & 0.1 & 1.6 \\
\hline & NE6 & 2.5 & 1.5 & 0.1 & NS \\
\hline & NE5 & 5.1 & 0.1 & 0.1 & 1.2 \\
\hline & Mean & 3.6 & 0.6 & 0.1 & 1.1 \\
\hline \multirow[t]{4}{*}{ North Dakota } & ND9 & 2.7 & 0.1 & 0.1 & 1.0 \\
\hline & ND11 & 3.9 & 0.1 & 0.1 & 2.0 \\
\hline & ND72 & 3.2 & 0.2 & 0.1 & 1.5 \\
\hline & Mean & 3.3 & 0.1 & 0.1 & 0.9 \\
\hline
\end{tabular}

${ }^{\mathrm{a}}$ The $1 \mathrm{x}$ and $2 \mathrm{x}$ rates were chlorsulfuron at 0.04 and $0.4 \mathrm{~kg} / \mathrm{ha}$ and glyphosate at 1.0 and $2.0 \mathrm{~kg} / \mathrm{ha}$.

${ }^{\mathrm{b}}$ Fisher's Protected LSD for one effect of rate (row) of each herbicide within each location.

${ }^{\mathrm{c}} \mathrm{NS}=$ non-significant at 0.05 or less.

${ }^{\mathrm{d}}$ Experimental plants not available.

${ }^{\mathrm{e}}$ Mean represents the average response for three clones from a collection location. 


\section{Acknowledgment}

We acknowledge Jennifer Haines, Peter Kujawski, and Lillian Zuback for their valuable technical assistance. We too thank Bruce Hoskins and Dave Yarborough for providing collections of Canada thistle, and R. S. Cranston, F. E. Northam, and Rich Old for providing collections of leafy spurge used in preliminary evaluations.

\section{Literature cited}

1. Alley, H. P. and C. G. Messersmith. 1985. Chemical control of leafy spurge. p. 65-78 in A. K. Watson, ed., Leafy Spurge. Monogr. 3, Weed Sci. Soc. Am., Champaign, IL.

2. Anonymous. 1989. Herbicide Handbook of the Weed Science Society of America, 6th ed. WSSA, 1508 West University Ave., Champaign, IL 61821-3133.301 p.

3. Barreto, C. L., L. O. Baker, and P. K. Fay. 1980. Variability among 12 leafy spurge (Euphorbia esula) ecotypes. Proc. West. Soc. Weed Sci. 33:50-51.

4. Carson, A. G. and J. D. Bandeen. 1975. Chemical control of Canada thistle. Weed Sci. 23:116-118.

5. Chism, W. J., S. W. Bingham, and R. L. Shaver. 1991. Control of Canada thistle (Cirsium arvense (L.) Scop.) on highway rights-of-way. Proc. Northeast. Weed Sci. Soc. 45:33.

6. Davis, D. G. 1985. The status of the leafy spurge numbering system. Leafy Spurge Symp. (GPC-14), Bozeman, MT 59717. p. 1-3.

7. Dunn, P. H. 1985. Origins of leafy spurge in North America. p. 7-13 in A. K. Watson, ed., Leafy Spurge. Monogr. 3, Weed Sci. Soc. Am., Champaign, IL.

8. Ebke, D. H. and M. K. McCarty. 1983. A nursery study of leafy spurge (Euphorbia spp.) complex from North America. Weed Sci. 31:866-873.

9. Evans, J. O. and J. M. Torell. 1986. Leafy spurge: a threat to crops and rangelands in Utah. Utah Sci. 47:63-66.

10. Gottrup, O. 1974. Translocation of Glyphosate and ${ }^{14} \mathrm{C}$-Assimilates in Canada Thistle, Leafy Spurge, and Toadflax. M.S. Thesis, Univ. of Alberta, Edmonton, Alberta.

11. Gottrup, O., P. A. Sullivan, R. J. Schraa, and W. H. Vanden Born. 1976. Uptake, translocation, metabolism, and selectivity of glyphosate in Canada thistle and leafy spurge. Weed Res. 16:197-201.

12. Haderlie, L. C., S. Dewey, and D. Kidder. 1987. Canada thistle biology and control. Univ. Idaho Bull. No. 666. p. 2-6.

13. Hansen, A. A. 1918. Canada thistle and methods of eradication. USDA Farmers' Bull. 1002. 15 p.

14. Harvey, S. J., R. M. Nowierski, P. G. Mahlberg, and J. M. Story. 1988. Taxonomic evaluation of leaf and latex variability of leafy spurge (Euphorbia spp.) for Montana and European accessions. Weed Sci. 36:726-733.

15. Hodgson, J. M. 1964. Variations in ecotypes of Canada thistle. Weeds 12:167-171.

16. Hodgson, J. M. 1968. The nature, ecology, and control of Canada thistle. U.S. Dep. Agric., Agric. Res. Ser. Tech. Bull. No. 1386. p. 4-9.

17. Hodgson, J. M. 1970. The response of Canada thistle ecotypes to 2,4-D, amitrole, and intensive cultivation. Weed Sci. 18:253-255.

18. Hunter, J. H. and L. W. Smith. 1972. Environment and herbicide effects on Canada thistle ecotoypes. Weed Sci. 20:163-167. 
19. LeBaron, H. M. and J. Gressel. 1982. Herbicide Resistance in Plants. p. 47-51. John Wiley and Sons, New York.

20. Lee, G. A. 197 1. The Influence of Selected Herbicides and Temperatures on the Carbohydrate and Protein Levels of Canada Thistle Ecotypes. M.S. Thesis. Univ. Wyoming, Laramie, WY. 196 p.

21. Lym, R. G. and C. G. Messersmith. 1985. Leafy spurge control with herbicides in North Dakota: 20 year summary. J. Range Manage. 38:149-154.

22. Manners, G. D. and D. G. Davis. 1984. Epicuticular wax constituents of North American and European Euphorbia esula biotypes. Phytochemistry 23:1059-1062.

23. Maxwell, B. D., M. V. Wilson, and S. R. Radosevich. 1988. Population modeling approach for evaluating leafy spurge (Euphorbia esula) development and control. Weed Technol. 2:132-138.

24. Radcliffe-Smith, A. 1985. Taxonomy of North American leafy spurge. p. 14-25 in A. K. Watson, ed. Leafy Spurge Monogr. 3, Weed Sci. Soc. Am., Champaign, IL.

25. Ray, T. B. 1984. Site of action of chlorsulfuron inhibition of valine and isoleucine biosynthesis in plants. Plant Physiol. 75:827-831.

26. Saidak, W. J. and P. B. Marriage. 1976. Response of Canada thistle varieties to amitrole and glyphosate. Can. J. Plant Sci. 56:211-214.

27. Slife, F. W., 1986. Resistance in weeds. p. 327-334 in E. H. Glass, ed., Pesticide Resistance: Strategies and Tactics for Management. Nat. Acad. Press, Washington, DC.

28. Tworkoski, T. J. and J. P. Sterrett. 1992. Phytotoxic effects, regrowth, and ${ }^{14} \mathrm{C}$-sucrose translocation in Canada thistle treated with mefluidide, flurprimidol, and systemic herbicides. J. Plant Growth Regul. 11:105-111.

29. Vaughn, K. C. and S. O. Duke. 1991. Biochemical basis of herbicide resistance. Chem. Plant Prot. 7:141-169.

30. Weier, T. E., G. R. Stocking, and M. G. Barbour. 1974. Botany, an Introduction to Plant Biology. John Wiley and Sons, New York. 651 p.

31. White, D. E. 1979. Physiological Adaptations in Two Ecotypes of Canada Thistle, Cirsium arvense (L.) Scop. M.S. Thesis, Univ. California, Davis, CA. 69 p.

32. Zuris, N. K., R. G. Wilson, and L. A. Nelson. 1987. Effects of plant growth stage on chlorsulfuron suppression of Canada thistle (Cirsium arvense) shoots and roots. Weed Technol. 1:10-13. 